\title{
Vintage Ladies in Cubist Exhibitions: Pablo Picasso's Cubist Women and Judith Butler's Performativity
}

\author{
Samaneh Saeid ${ }^{1}$, Laleh Atashi ${ }^{2}$ \\ Shiraz University, IRAN \\ e-mail: samanesaeid1992@gmail.com¹, laleh.atashi@shirazu.ac.ir²
}

\begin{abstract}
As a prominent figure in the history of painting, Pablo Picasso has bestowed upon the world his uniquely striking paintings in different styles, the most revolutionary of which being his Cubist art. The representation of women occupies a significant space in Picasso's Cubist works. While the painter's style is highly revolutionary, rejecting the accepted principles of painting, the subject matter does not change as such: nude women are objectified with a cubist look. Judith Butler's theory of gender performativity which examines the roots of naturalized concepts of gender, has been applied to Picasso's representations of women in his cubist paintings. This research examines the way naturalized definitions of gender have found their way into Picasso's paintings. By applying the Butlerian concept of gender performativity to a number of Picasso's cubist artworks, we try to indicate how stereotypes of gender linger in the discourse of modernism. Analyses lead to the conclusion that although the cubist style of painting is an experimentation in form, hardly any avant-gardism can be traced in the representation of gendered identities in Picasso.
\end{abstract}

Keywords: Cubism; naturalization; objectification; performativity; revolutionary.

\section{INTRODUCTION}

Representing gender identity has often been part and parcel of artistic productions. Both written and visual types of art have been anchored as enchanting canals through which the producer's ingenuity imbued with cultural inculcations have been germinated. Celebration of cultural integrity and conventional importance has sundry manifestations in verbal and visual art: the enshrining of religion as the sole provenance and purpose of human beings in Middle Ages, the appreciation of Nationalism and cultural preservation during Renaissance, the elevation of decorous tastes of Enlightenment intellectuals have all found their ways in the artistic productions within different ages. With the emergence of Modernism and the cries of loss, decay, darkness and hopelessness, the disintegration of cultural norms gained momentum in the artistic canon. As we move further into the 20th Century, and with the development of social theories, the long-subdued voices, including voices of women, racial minorities, and cultural others could be more often heard. Since our focus in this article is on the representations of femininity in cubist art, the consideration of cultural definitions of gender is of particular importance to us. Along with the gradual empowerment of women, a greater attention is being paid to the notions of femininity, female representation, female experience, female subversion, female suppression and female resistance as depicted in the works of art in different historical periods. In this article, we try to figure out the extent to which patriarchal ideologies and the discourse of the New Woman at the beginning of the twentieth century are (not) counteracting each other in Picasso's paintings of the female body.

William Desmond (2001) has claimed in Ethics and the In Between, that "the image seduces unformed desire.... [and] also may be an exemplary life that unlocks ethical hope. It may release a reserve of longing that carries us towards the unconditional good, a reserve we thought dead or nonexistent" (Desmond, 2001, p.230). Building upon the seductive power of the image, the art critic can scrutinize paintings to find out how they can take their turn in constructing, deconstructing or even reconstructing cultural values. Generalizations should be avoided but it is undeniable that different social discourses naturalize many a notion for the sake of certain ideological intentions; such internalized notions can be traced in such cultural products as paintings. Gender ideologies that define certain roles for people of different sexes abound in visual media in general, and in artistic productions such as paintings in particular. This article examines the way gender is represented through colors, lines, forms, and compositions in Picasso's paintings. 


\section{CULTURAL RE-THINKING OF GENDER IDENTITY THROUGH BUTLER'S PERFOR- MATIVITY}

Butler, observing the enterprise of even daily actions, has settled on the 'concept of identity' and 'gender evolution' with a skeptical outlook toward their inevitability. The construction of authoritative regulations and the naturalization of these politically significant stipulations are of exorbitant importance in Butler's cultural theories. Butler (1988) holds that the culturally represented gender is not rooted in some transcendental essence and builds upon Simon De Beauvoir's distinction between biological sex and the culturallyconstructed gender, as well as Merleau-Ponty's belief in the absence of a predetermined interior essence for gender-generation (Butler, 1988). Salih (2002) emphasizes that the construction of gender identity is shaped by language. Consequently, the 'personal is political' hypothesis elucidates the absorption of the predetermined political intentions by the individuals, a process which adulterates the pure representation of the individual subjects in the society. Butler dissolves the binary of sex/gender and holds that sex is already gendered from the beginning of its social existence, because "there is no existence that is not social" (as cited in Salih, 2002, p.55). Therefore, there is no unadulterated sexual identity that pre-exists social inculcations. The futility of the pure representation of the concepts has been allocated to the inculcations of the political structure:

The political construction of the subject proceeds with certain legitimating and exclusionary aims, and these political operations are effectively concealed and naturalized by a political analysis that takes juridical structures as their foundations, Juridical power inevitably "produces" what it claims merely to represent: hence politics must be concerned with this dual function of power: the juridical and the productive (Butler, 1990, p.2).

She clarifies the point further when she says that one cannot 'think that the discussion of 'identity' ought to proceed prior to the discussion of gender identity for the simple reason that 'persons' only become intelligible through becoming gendered in conformity with recognizable standards of gender intelligibility" (Butler, 1990, p.16). What Butler tries to manifest is the fact that social agents become members of society only after they identify themselves as dependent agents; this process includes the identification with gender as well. Consequently, social agents have already been gendered. Salih (2002) has described that the politically supreme forces of the society make the repeated acts of gender roles congeal over time and incorporate in the individuals' systems of belief.
In the Bodies that Matter, Butler (1993) emphasizes the notion of "heterosexual imperative" and attributes it to the "reiterative" and "citational" practice of social consolidations (Butler, 1993). The process of socialization, actually comprised of the repetition of politicized norms rooted in the fundaments of the society's framework; however, the non-stop repetition of the imposed politicized regulations on the subjects is all that matters. The internal authority of the frequent reiteration of social rules is highly influential in shaping social identities to the extent that naturalization occurs through this causality of socialization. Butler (1993) asserts that the "substantive effect of gender is performatively produced and compelled by the regulatory practices of gender coherence" (p.25). The reflection of gender, gender identity and gender crisis in verbal and visual art, therefore, could be attributed to the naturalized and naturalizing frameworks internalized by society at large. Different works of art can give voice to gender discourses circulating in the context in which the work of art has been conceived and born.

\section{WAR OF THE CUBIST TECHNIQUES IN PICASSO'S ART}

Possessing three phases of artistic illustration, Pablo Picasso projected his world of colorful thoughts through Blue Period, Rose Period and eventually Cubist Period. Cubism as a modern representation of the real world registering an artistic resistance to traditional methods of realist painting, comprising of life-like and curve-inclined techniques, became prevalent in the modernist era. This conceptual response to the conventional representation of the external world reflects life through its geometric units that appear jagged and shocking to the viewers. The magnified and "un-life-like" presentation of the world must have been extremely appalling to the addressees who were used to see proportionate and decorous artistic techniques. Paying attention to the two harbingers of this style, Pablo Picasso (1881-1973) and Georges Braque (1882-1963), Krauss (1992) argues that these painters pronounced the impenetrable frontality of the pictorial more obstinately and resolutely than had any style before it, so that the little areas of modeled form that heave into relief like so many swells on the surface of a lake, hit the shoals of the picture support with a finality that could only dissipate their energies into a lateral spread, never implying a further plumbing of that support into a space behind. Modeling in this sense becomes the empty trappings of an illusionist system more and more divorced from the business of illusionism, a business we could describe as giving us access through the vehicle of sight to reality in all its carnal fullness to its weight and density, to its 
richness and texture, to its heat and vaporousness, to the evanescence of its very perfume. (pp.261262)

By creating the possibility of engaging both the visual sensation of the viewers and their tactile perception, Cubism prepared the piercing elements of the pictorial shock with the intention of presenting reality in its nude and magnified quality. Arbiter (1917), who has regarded Cubism as a degenerated form of art advocated the belief that it is the moral degeneracy of the modern world that has begotten the counter-natural style of Cubism:

Nature abhors the straight line, even more, the rectangle and cube avoid them when possible, and always seeks the curve. There are almost no rectangles in nature and few, if any, cubes even among the lowest crystals. It is the curve which dominates nature. Our eyes, mind, and soul are adjusted to the curve. Therefore, there is nothing so disagreeable to us, in form, as a severely plain and empty picture frame of say about a yard square... When a frame is filled with a picture full of curves we forget the frame because the mind is focused upon the picture; but an empty frame on a wall is a disagreeable object simply because its angularity at each corner shocks the eyes (p.426).

The "appalling nature" of the cubist style has been considered as a "sudden apparition" by Arbiter. His description of Cubism is incompatible with nature's inclinations and rules; while "nature never somersaults, she always transforms", Cubism is a without-warning revolution (Arbiter, 1917, p.427). Whether or not it is fair to allude to Cubism as oppositional to the laws of nature or as a form of moral degeneracy, depending on the definition of art and nature, yet it is certainly veritable that this opposition could give severe shocks to the audience used to observe the realist artistic fashion. To escort a counter-argument by Picasso himself, one ought to be mindful of the painter's own belief in his natural style where he purports that: "I attempt to observe nature, always. I am intent on resemblance, a resemblance more real than the real, attaining the surreal. It was in this way that I thought of Surrealism..." (as cited in Golding, 1980, p.20). While Picasso's cubist style purportedly negates natural rules of representation, it can also be said to be closer to nature since his cubist style is untainted by imposed conventions of art. Cubism had to find its way open into a world of art the conventions of which were strengthened by age-old aesthetic theories praising representational art:

In his attempt to achieve the sort of hyper-reality he sought for in his art Picasso resorted to an infinity of devices. ... he was to achieve the "more real than the real" through his use of expressive distortion by altering the natural appearances of objects, and above all of the human body, in order to jolt the spectator out of conventional modes of perception and into a new and heightened awareness of the visual world (Golding, 1980, p.20).

Schneider's (1947-48) analysis of the reality depicted by Picasso is very much in line with the previous argument:

Indeed it is as though Picasso created a new world of reality "behind or beyond reality" peopled with new creatures tantalizingly related to the creatures we are and recognize around us and yet not of this world, as though a man from another planet equipped with different visual physiology - with different perceptual interpretation - had recorded his impressions of us. This is one part of Picasso's great contribution (p. 85).

Although the mode of pictorial presentation is revolutionary in Cubism, the culturally structured mindset of the painter, regarding the representation of gender attributes, is not that revolutionary. While being a forerunner of an Avant-garde style, Picasso does not break through patriarchal conventions in his representations of the female body: when featuring the female body, he reiterates the cultural definitions of gender with a different approach. Those of his paintings featuring the female nude can be taken as noted examples in which the nude poses for the male gaze, as she did before, but the whole scene is peppered with exotic flavors and edgy contours.

Les demoiselles d'avignon (1907) "seemed to everyone something mad and monstrous," says Daniel-Henry Kahnweiler, an art dealer (as cited in Chave, 1994, p.261). Obviously, the expected conventions $\mathrm{s}^{\mathrm{i}}$ of illustrating prostitutes have been collapsed by the promotion of this painting. Some critics attributed Les demoiselles d'avignon to Picasso's deep-seated distaste for women: 'Picasso's feelings of revulsion for the female body were projected in the first state of the demoiselles through a narrative specificity" (Rubin, 2014, p.630). The revolutionary style of Picasso created an uproar among critics and caused diverse interpretations. Chave, for example, comments on the sexual encounter between Picasso and the nude models. According to Chave (1994):

In the standard art historical narratives, however, these violations on the artist's part tend to get conflated with the putatively violent aspect of the women he depicted, who often come to assume a kind of autonomous agency. And whereas Picasso's contemporaries fingered him as the perpetrator who "attacked" his female figures, later accounts often cast the artist together with the viewing public as the prostitutes' victims (p.596). 


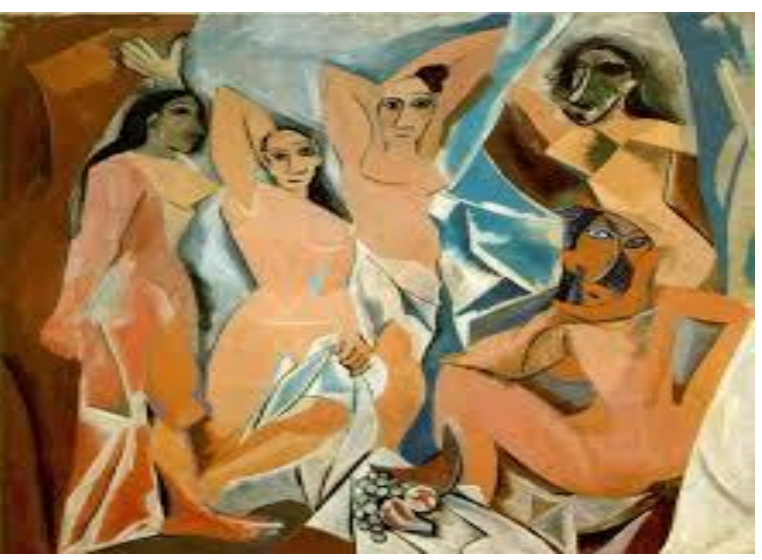

Figure 1. Les Demoiselles d'Avignon (1907)

Based on Chave (1994), there are manifold prescripttions of this painting by various critics regarding Picasso's bold expression of the female body and the painting's violent foray on the audience. Leo Steinberg, the art critic, and historian, considered the painting as a "tidal wave of female aggression... an onslaught;" Robert Rosenblum, the art historian, referred to the painting as an "explosion" goaded by "five nudes (who) forced their eroticized flesh upon us with a primal attack," and eventually Max Kozolff, the modern art critic, and art historian considered this painting "a massacre" (Chave, 1994, p.596).

Racial positionalities can be traced in the painting; the centralization of relatively whiter women and the placement of black faces on the left and right margins provoke Eurocentric codes of beauty and the center/periphery dichotomy prevalent in Eurocentrism. Lack of any animated emotion in the eyes of these women has turned their semblances into poker faces inspiring the idea of the masque. The void looks on the faces of these women frustrate the male desire for pornographic spectacles. The poses are not unfamiliar: arms pulled up, breasts accentuated, and sitting gestures that exhibit the body can be found in many nude paintings of previous ages, nevertheless their absent look has transformed them into performers uninvolved in what they do. They seem to be tired of the role nudes played throughout art history. Not only senseless eyes but also the cubist bodies help to move the painting further away from the expected representations of erotic flesh. The robot-like mood of the women and the sharp angularity of their body can even repel the audience. Supposedly, while Picasso has created unconventional women who scare off the male gaze by their jagged angularity, he reduces them to somatic objects with no way out of the conventions of art history.

The reiterated representation of the exposed female body as seductive before Picasso and as Femme Fatale by Picasso Reff, (1973), is rooted in the cultural cultivation from Butler's point of view: the painters are seemingly limited to choose among few options to represent women. Butler's wardrobe analogy helps to illustrate the limited choices of gender representation; "one's gender is performatively constituted in the same way that one's choice of clothes is curtailed, perhaps even predetermined, by the society, context, economy, etc. within which one is situated" (Salih, 2002, p.56). Shedding light on the culturally restricted choices of the painters, the pre-determined definitions of female representations by culture are to be compared to a closed framework where clothes have been chosen and put to use without the free intrusion of the users.

By the same token, in Girl Before a Mirror (1932) the artist seems to have drawn upon a set of predetermined accessories that gender ideologies have made accessible to society. To extend Butler's wardrobe metaphor, one can say that the girl has put on what she had access to in her cultural wardrobe: a set of accepted facial and physical characteristics which would facilitate her visibility. Girl Before a Mirror (1932), showing the representation of a girl observing her own reflection through a mirror, features subtle contrasts between the girl and her image reflected in the mirror. Umland (2012) cites Robert Rosenblum, the art historian, who has described the painting this way: ... a smoothly painted, delicately blushing pinklavender profile combined with a heavily builtup, garishly colored yellow-and-red frontal view, as a marvel of compression containing within itself allusions to youth and old age, sun and moon, light and shadow, and merging ... one of the most pervasive cultural myths about women inherited from the nineteenth century, the polarity between virgin and whore, archetypes that haunted Picasso from his earliest years (p.2).

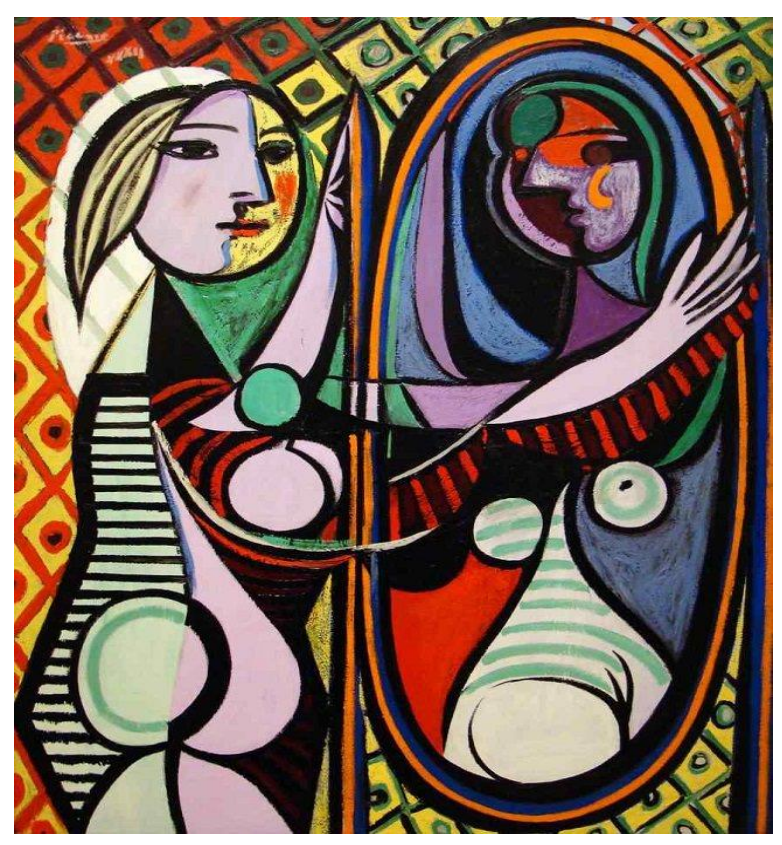

Figure 2. Girl before a Mirror (1932) 
Umland (2012) continues the description and states that "Her reflection, on the right, further complicates the picture, introducing a shadowy, introspective doppelgänger into the painting's compressed and chromatically overheated space" (p.2) The contrast between the roseate complexion of the girl before the mirror and the dark face in the mirror could also feature the dichotomy between public self and private self. Thus, the idea of social masque and prescribed gender roles come to the fore, while the reflection in the mirror suggests a morbidly ailing ego darkened, reddened and overshadowed by unilluminated pigments implying loss, misplacement, and imprisonment. Additionally, pregnancy and childbearing as conventional roles for women have also been depicted in the painting. The presence of the pregnant belly in the picture can be an apt situation to grasp Butlerian notion of gender politics as the process of self-identification. While the young lady could possess an independent status at least in the realm of imagination, she is culturally programmed to suppose inculcated fantasies even in the world of freedom. The womb-like mirror significantly has been held upright to suggest that the birth of a hopelessly dark individual is inevitable. The wallpaper's pattern of circles within rectangles could be suggestive of a never-ending chain of matrixes with a seed inside, abstract representations of pregnancy. The mirror bespeaks the inevitability of reflection. Is the woman like the mirror, a reflecting device echoing what the outside world demands of her? While the girl is reflected in a gloomy status in the mirror, there is no way for her to escape from being represented, reflected, and echoed. Her hands have the cheval glass used for dressing. Once more, Butler's wardrobe analogy comes to mind. The dresses, faces, and masques available to users are limited. The roseate girl is also the reminiscent of Echo, the mythological figure who was under the curse of Hera, the Greek goddess of marriage and childbirth, to repeat only the words of others. Hera as a patriarchal woman debilitates Echo and makes her dependent on the words of others. Picasso's painting features an Echo, mourning her plight. Caught within the loop of cultural definitions of gender, the masked girl is expecting the doomed birth of her child. Seeing no chance to perform an identity independent from cultural norms, the girl in the mirror wittingly mourns her lost chances of a free life.

Girl with a Mandolin (1910), a nude woman playing a musical instrument, is barely the representation of a woman's musical talent than a moment of voyeuristic auditory pleasure. The curves in the painting can be found in the girl's tresses, her right breast, and the mandolin that she is playing. The rest of the lines are jagged and angular. Playing the music might seem to offer the girl a degree of artistic agency and autonomy, but again she gets objectified and essentialized as a sexual being when her femininity is spotlighted in the curves of her hair, her breast, and her musical instrument: the curve of the musical instrument echoes the curve of her breast and hence, she and the music that she is playing are one and the same. Since there is no sharp color contrast between the girl and her background in this painting, it can be said that the girl with the mandolin does not stand out and sinks in the background in which she has been depicted. It is an artistically ultimate version of the body dislocation and a painting "very beautiful in its achievement of the shimmering effect of moving planes and shifting areas of color, in sunlight and shadow" (Schneider, 1947-48, p.85). The painting registers "an infusion of an inordinately high psychic tension achieved pictorially by various methods of distortion; and second, a playing with time and space in relationship to the mass and dimensions of the body" (p.83). As can be seen, light and shadow and the psychological depth of the painting have been highlighted by art critics but the sociological construction of gender seems to be amiss from such criticisms. The women's artistic ability has not overshadowed her physicality in this painting; the curly prepossessing golden hair perspicuously beautified by the concentration of the golden cast of the background, the slim feminine figure accompanied by highlighted curves with the slanted coy angle she possesses in her standing position could be considered as the penetratingly codified conventions through which femininity has been culturally defined.

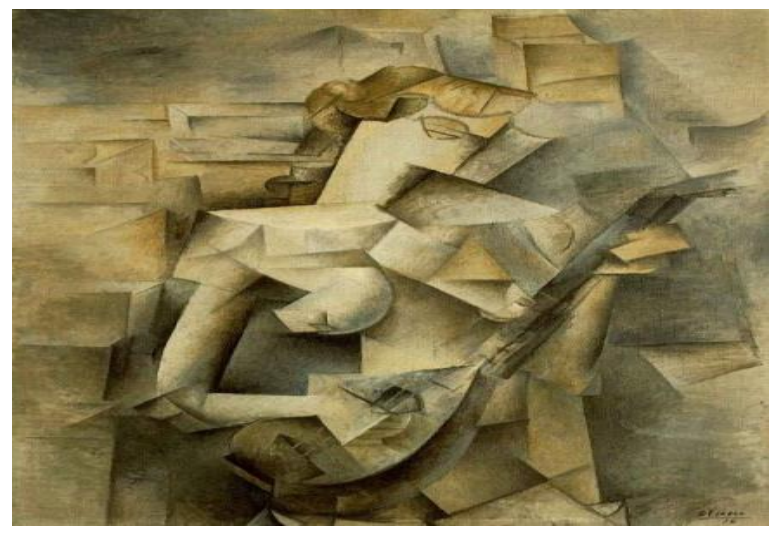

Figure 3. Girl with a Mandolin (1910)

Three Musicians (1921) is a large-scale painting portraying three male musicians holding their musical instruments. It is actually parallel to Girl with Mandolin in its portrayal of musicians and their artistic tools but engages itself in the discussions of gender and power differently. While the girl holding a mandolin is sparklingly delicate regarding her physics, the three men in 1921 painting attract the viewers' attention to their artistic power. The concentration of spectators will be placed on the verve and vivid enthusiasm of 
these three people playing music since they are actually in disguise being covered by loose robes and sheathes with no transparent indication of masculine bodily figures. As Bailif in her analysis of this amazing 1921 portrayal clarifies, the musician in between is Picasso himself covered by a piece of colorful cloth signifying the Spanish flag manifesting a highlighted sense of nationalism. This painting's ability to communicate entirely different messages such as nationalism and jingoism through the vivid subject of musical instruments played by three musicians could indicate nationalist sentiments through art; besides, the presence of a stretched and distorted animal figure could connote the concept of instinctual violence. The painting, therefore, can be interpreted as a pictorial representation of Spanish nationalism and spirit maintained through masculine prowess. The plain background with a brownish cast is in sharp contrast to the wildly colorful clothes of the musicians, thus the male artists are distinguished and outstanding in their milieu.

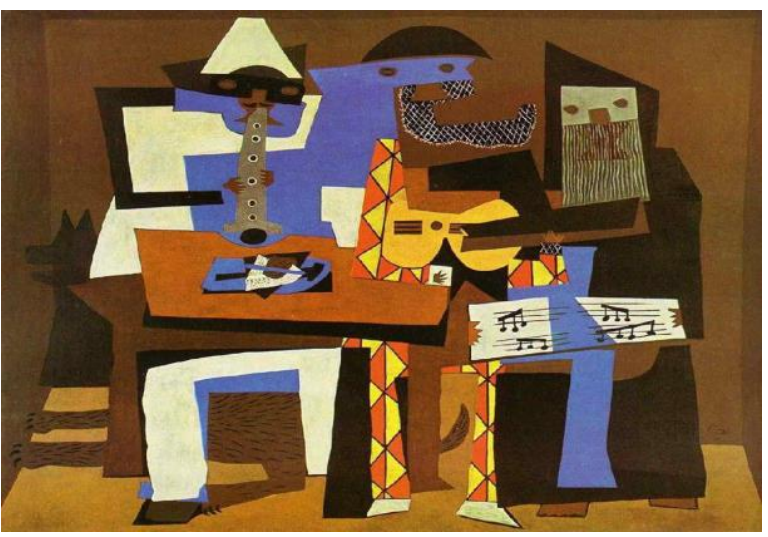

Figure 4. Three Musicians (1921)

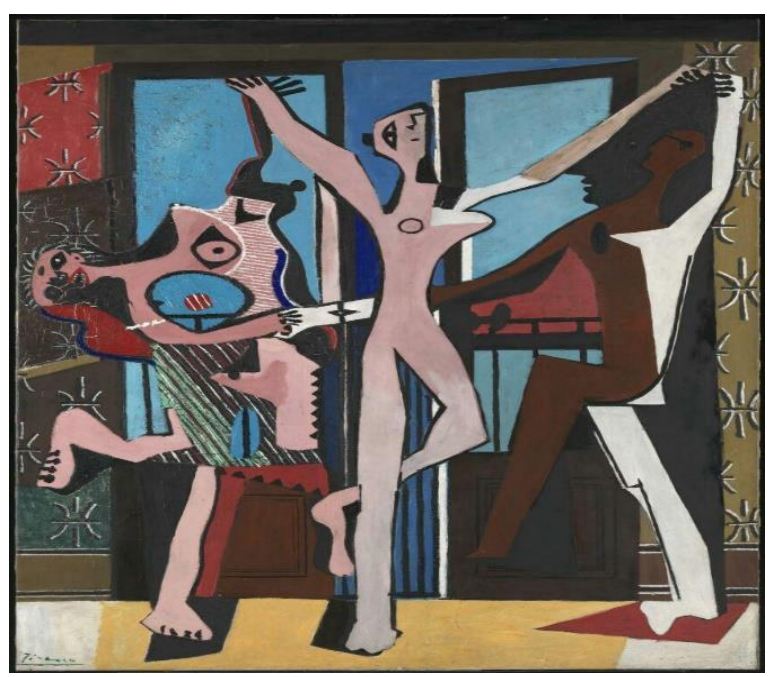

Figure 5. The Three Dancers (1925)

Three Dancers, another trident representation of figures could be viewed as the amalgamation of triangular concepts of darkness, ecstasy and grotesque; the implication of annihilation, vitality, and rejuvenation accompanied by frenzy and insanity could be grasped respectively. Reff (1973) believes that the manifestation of a range of wild feelings is a recurrent image in Picasso especially in those works featuring unrestrained images of femme fatale. Picasso's femme fatale "is a figure whose grotesque expression and abandoned posture suggest simultaneously the opposites of grief and ecstasy, embodying in a concentrated, paradoxical form that deep conviction of the fatality of love must already have crystalized in his mind around her person many years earlier" (p.25). Worthy to consider is the superimposition of feminine somatic features over women's artistic ability. Very much resembling Les demoiselles, this painting mixes races, shapes, and gestures. Despite their artistic performance, the dancers' horrifying nudity grasps the attention of the viewer. Although powerful in some sexual aspects, these women cannot be considered mediocre human beings with normal attributes. The absence of mothers, angels of the house, and obedient daughters, in Picasso's paintings, can be dubbed as ground-breaking, but the exoticizing female body is far from being unprecedented. While conventional paintings manifested well-formed women in tune with social assumptions about femininity, Picasso revolutionized women's role in that he does not beautify, idealize or harmonize female body, but his avantgardism lies in his taste for grotesquerie. Women are objectified not as appealing sexual beings, but as grotesque sexual beings. The three dancers are holding hands, but their faces and bodies are seemingly aping the idea of harmony and beauty that can be traced in such classics as "The Three Graces" by Raphael (1504-1505).

To debunk the origin of inspiration that propels Picasso's Cubist innovations, one can trace the footsteps of African primitive art. Picasso is believed to have returned to the unrefined, un-camouflaged aspect of nature; in other words, Pennisi (n.d.) has identified Picasso's cubist tradition as the representation of pure art with no Western beautifying techniques. To the writer Picasso got enchanted by the simplified depiction of the external world through African art; the metamorphosis of his works could be said to have been originated from black artistic production (Pennisi, n.d, para.14). The reversed perspectives Picasso seems to have had in grasping the external world are actually involved in the modernist notion of refuting recent traditions namely racial propagandist enterprises ${ }^{\mathrm{ii}}$. While the inclusion of black faces as the refutation of racial biases is evident in his paintings, when it comes to the ideology of gender, his artistic landscape is not inclusionary since it is peopled 
by female figures that are objectified and othered by patriarchal gaze. Picasso is unwilling or unable to revolutionize the notion of gender in his depiction of women despite his iconoclastic style. While he was successful in subverting conventional painting styles, the painter reiterated the cultural definitions of gender with a different approach.

\section{CONCLUSION}

As a wedding gift to Picasso, his beloved friend Guillame Apollinaire, wrote him a poem which reads: "Our God now wants to help us, / his children wise, courageous / so may he bless our weddings, poems and painting, / and one day like the stars above, / along with these dear ones we love, / dear Pablo, may he let us be singing for all eternity" (Nancy, 2015). Apollinaire's blessings have apparently come true since Picasso's unprecedented style, especially in Cubism, remains new for all spectators of all times. His everlasting language in painting reflects the pure reality, artistically summarized in war, cruelty, eroticism, pain, and agony. Picasso proclaimed that his paintings were definitely his autobiography portraying what he felt rather than what he saw. His powerful fantasy in the perception of the world has bestowed upon his paintings a universal flavor hardly achieved by others. The presence of Picasso's nudes, capturing his perspective toward women as either goddesses or doormats (Hudson, 2016, para.1), enunciates the bitter universality of what it means to be a woman. The aesthetic bitterness of his cubist nudes inspires both appreciation and frustration; the de-familiarized representation of women places Picasso in an elevated status through which the audience can experience both desire and despair.

\section{REFERENCES}

Arbiter, P. (1917) A degenerate work of art: A cubist creation. The Art World, 1(6), pp. 426-427, 424. doi: 10.2307/25587822. Retrieved from: https://www.jstor.org/stable/25587822.

Bailif, L. (n.d.). Personal interview. Retrieved from: https://www.youtube.com/watch? $\mathrm{v}=\mathrm{GKquUggz}$ qpg.

Butler, J. (1988). Performative acts and gender constitution: An essay in phenomenology and feminist theory. Theatre Journal, 40(4), 519-531. Retrieved from: https://www.amherst.edu/system/files/media/1650/butler_performative_acts.p df.

---. (1990). Gender trouble: Feminism and the subversion of identity. New York: Routledge.
---. (1993). Bodies that matter: On the discursive limits of the "sex." New York: Routledge.

Chave, A.C. (1994). New Encounters with Les Demoiselles d'Avignon: Gender, race, and the origins of cubism. The Art Bulletin, 76(4), 596611.

Desmond, W. (2001). Ethics and the in between. New York: State University of New York Press.

Golding, John. (1980 December). Picasso's Distortions. The Unesco Courier. 20-23. Retrieved from: http://unesdoc.unesco.org/images/0007/ 000747/074766eo.pdf.

Hudson, M. (2016 April 8). Pablo Picasso: women are either goddesses or doormats. Retrieved from: https://www.telegraph.co.uk/art/artists/pablopicasso-women-are-either-goddesses-or-doormats/.

Krauss, R. (1992). The motivation of signs. In L. Zelevansky (Ed.), Picasso and Baroque: A symposium, (pp. 261-286). New York: The Museum of Modern Art. Retrieved from: https://monoskop.org/images/f/fc/Krauss_Rosali nd_1992_The_Motivation_of_the_Sign.pdf.

Nancy, H. (2015). Picasso, love, sex and art. Retrieved from: https://www.youtube.com/watch? $\mathrm{v}=\mathrm{CS}$ CopzsBC9c.

Pennisi, N. (n.d.) Picasso and Africa: How African art influenced Pablo Picasso and his work. Retrieved from:

https://www.palmbeachstate.edu/honors/Docum ents/picasso_and_africa_how_african_art_influe ced_pablo_picasso_and_his_work_nadeenpenni si.pdf.

Reff, T. (1973). Themes of love and death in Picasso's early works. Retrieved from: https://www.artforum.com/contributor/theodore-reff.

William, R. (1983). From narrative to "iconic" in Picasso: The buried allegory in Bread and Fruitdish on a Table and the role of Les Demoiselles d'Avignon, The Art Bulletin, 65(4), 615-649. doi: 10.1080/00043079.1983.10788115.

Salih, S. (2002). Judith Butler. Routledge Critical Thinkers Series. New York: Routledge.

Schneider, D, E. (1947-48). The Painting of Pablo Picasso: A psychoanalytic study. College Art Association, 7(2), 81-95. Retrieved from: http://dvalentin.pbworks.com/w/file/fetch/81287 423/Picasso\%20A\%20Psychoanalytic\%20Stud y.pdf.

Umland, A. (2012). Picasso: Girl Before A Mirror. [Review of the painting Girl Before A

Mirror by P. Picasso]. New York: Museum of Modern Art. 


\section{Notes}

${ }^{\text {i }}$ Seductive faces, corpulent bodies, mincing gestures and inviting glances placed in tempting locations are of egregious signs through which prostitution has been publicized. ii According to Pennisi, during "Scramble for Africa" (1876- 1912), African art was brought to some countries including France, where Picasso lived at that time. It's been argued that African art had no aesthetic values but Picasso's assimilation of African attributes in white art gave aesthetic color to African heritage. This could be considered as a great welcome to a neglected tradition. 